\title{
Professional self-development of future specialists in the field of ecological psychology in the context of distance learning
}

\author{
Natalia Filina ${ }^{1, *}$, Marina Zemsh ${ }^{2}$,Elena Petrova (Sorina) ${ }^{1}$, and Elena Petrova ${ }^{2}$ \\ ${ }^{1}$ Russian State Social University, 129226, Wilhelm Pieck street, 4, build.1, Moscow, Russia \\ ${ }^{2}$ State University of Humanities and Technology, 142600m, Zelenaya street, 22, Moscow Region, \\ Orekhovo-Zuevo, Russia
}

\begin{abstract}
Professional self-development as is one of the key targets of the higher education system. The digital transformation of the professional training sphere analyses the features of future specialists' self-assessment of individual ability to transform themselves, their living conditions and professional activities. The information about the influence of the distancelearning format on professional self-esteem and self-development in future specialists are poorly systematized in the modern scientific literature. The aim of the article is the study of future educational psychologists and social educators' attitude to the distance learning as a resource for selfdevelopment, the analysis of the correlation between future professionals' quality evaluation of the organization and content of distance learning process in the period of the pandemic and self-assessment of their skills. We used the empirical methods: survey methods to collect data from respondents. The subject is the opportunities for self-development of the future specialist of the psycho-pedagogical fields in the conditions of distance format of obtaining a profession. The mathematical and mathematical statistics methods were used. The sample set of respondents consisted of 57 2-4 years students of full-time and part-time education of the Faculty of Psychology and Social Pedagogy of the State University of Humanities and Technology, Orekhovo-Zuyevo.
\end{abstract}

\section{Introduction}

One of the most serious challenges to modern humanity is COVID-19. It was thrown against the health and life of people, but it served as a powerful impetus for the growth of the digital economy in the world developed countries. It stimulated the spread of virtual communications, the development of electronic resources and technologies in various fields of activity, while put the world educational system in front of the global issue of re-evaluating the effectiveness of existing models of preparing the growing generation for life in a completely different reality. The present day of humanity implements the forecasts of the

\footnotetext{
${ }^{*}$ Corresponding author: sinebroffka2005@gmail.com
} 
foresight concepts of futurologists describing the world of the virtual future. It is obvious, that education will never be the same.

Digital transformation puts forward new requirements for the professional competencies of not only teachers, but also specialists who provide psychological and pedagogical support for students. This transformation actualizes discussions around the value-semantic and content aspects of education as a global social trend.

Against this background, the issues of professional self-development of future specialists in helping professions of psychological and pedagogical profile, which according to the Russian tradition include educational psychologists and social educators, acquire new accents.

We aimed to study the opinion of the future educational psychologists and social educators about the quality of their professional training in conditions of distance learning, how they feel and assess the given experience of distance learning in their future profession from the self- development point of view.

The analysis of the literature shows that the phenomenon of professional selfdevelopment specialists of psychological and pedagogical profile has not been the subject of special study in pedagogical science, however, the theoretical and methodological base for the research component of self-development of the teacher-psychologist and social educator amounted to psychological theories of personality development by A. Adler, B. G. Ananiev, L. Vygotsky, Leontiev A. N., Rubinstein S. L., the conceptual provisions on the stages of professional development of Parson F. , Super D., Holland D. and professional activity Klimova E. A.,, the theoretical concepts on the development of professionally important qualities Gonobolina F. N., the approaches to the professional formation of social educators and educational psychologists Bocharova V. G., Mudrika A.V., etc.

However, the theme of professional self-development in the conditions of distance educational system is largely presented in organizational, procedural and managerial aspects in the recent years studies. The works of Biryukov M. S. [1], Grushevsky S. P., Ivanov O. V. [2], Sergeev N. I. [3], Sharonin U.V. [4] may be of interest in this context. The works of: E. U. Azbukin, L. V. Voloshin [5], Miniyarov V. M., Esterle A. E. [6] can be useful in the psychological and pedagogical aspect.

The following works, covering the issues of self-development in relation to the pedagogical field of activity can be distinguished in modern foreign literature: Danijela Makovec [7],Ine Noben, Jan Folkert Deinum, W. H. Adriaan Hofman [8],Berit S. Haug, Sonja M. Mork [9],Sarah Prestridge[21], Antjevon Suchodoletz, Faiza M.Jamil, Ross A.A., A.Larsen, Bridget K. [11], David J.Osman, Jayce R.Warner [12],Jessica Cira Rubin[13], Dirk Richter, Marc Kleinknecht, Alexander Gröschner[14;19],LoganRutten[15], Gaowei Chen[16], Soobin Choi, Xinyi Mao[17] ,Teomara Rutherford ,Jennifer J.Long, George Farkas [18], Aksu M. B., Apaydın Ç., Kasalak, G.[20].

The work "Categorizing teachers' use of social media for professional learning: a selfgenerating paradigm of professional learning» which reflects an attempt to study the reasons of using the specific social networks can be interesting for our research. There was a survey of experienced ICT teachers about their conceptualization of professional training and online activity connected with it. These recognized experts in the field of ICT from Australia, Europe and the United States of America has been specially selected for the study. The experienced teachers used the social media differently. They were based on their own professional learning concepts in these online spaces. The results represent a typology of reasoning based on two continuums: Me and Interactivity. The four categories of teacher involvement in networking proposed in the article are of practical significance. The new paradigm of professional self-development, which is important for understanding of social media in the professional training of teachers, is presented in the study. This paradigm is already important for changing the filed, which we consider effective professional 
development and desire to maintain the topicality of innovative ideas in this dynamic field [21].

The article «Novice Teacher Self-Efficacy Belief: A Study of Scale Development» is of interest From the point of view of developing tools for assessing self-development. The aim of this study was the developing of New Teacher Self-Efficiency Belief Scale (NTSB). This toolkit can be used for conducting empirical studies of professional self-assessments of teachers [20]. The article "Developing a teacher's professional identity through digital stories" describes an innovative teaching and diagnostic tool. The digital stories can become such tool in the format of professional education, allowing students to convey complex concepts and emotions both through linguistic and non-linguistic methods. The digital history is a 3-6 minutes multimodal video. This study analyses how beginning teachers have used the digital storytelling for the formation of their professional identity. The results show how the digital storytelling can help teachers to reflect and develop as professionals. Also, the article shows and illustrate an innovative systematic functional linguistic approach to analyzing digital stories as complex multimodal objects.

The young teachers face the challenges in the sphere of professional communication on the way to professional development. Meanwhile, they are not ready to solve the practical tasks of study and they are not experienced enough in the sphere of modern teaching methods. The article concludes the young teachers need more opportunities for professional development, especially for active teaching methods and group teaching. We can increase their chances for successful adaptation to school standards. It is needed to give them an adjustment period for supporting their motivation and preventing the escape of young stuff from school because of the low job satisfaction. The analysis of the article's materials can identify the problem areas of professional self-development of teachers. The reviewed literature suggests that there is not many works in context of study the phenomenon of professional development of teachers under the digital educational paradigm. These works reflect only the organizational and managing methods of transferring the experience or describing the essence of distance learning technologies.

The experience of foreign researchers can be interesting from our point of view. It consists of describing the practice of realization of interactive pedagogical technologies, which help to study the features of professional self- development, and professional realization of a teacher. While, the overview of scientific works let us to make a conclusion, the scientific theory of professional self- development, which can be applicable to social education and educational psychology activities, practically does not exist. The understanding of theoretical and empirical incompleteness in the study of this pedagogical phenomenon became the basis of our study.

\section{Materials and methods}

We have implemented this study using the survey method (Questionnaire of full-time and part time education students). There were used some mathematical methods and mathematical statistics or correlation analysis for processing students responses. The sample set of respondents consisted of 57 2-4 year students of full-time and part-time education of the Faculty of Psychology and Social Pedagogy of the State University of Humanities and Technology, Orekhovo-Zuyevo.

\section{Results}

During the study, students of full-time and part-time education had to decide the impact assessment about distance learning and their self-assessment of professional competence. 
The survey during the study showed that the intensity of communication between students and teachers decreased in conditions of distance learning. This was stated by $41 \%$ of respondents among full-time students and $37 \%$ among part-time students. The number of respondents, considering that interaction with teacher become easier, is half as much regardless the form of education. More than a half of students, participating in the survey, named the opportunity to plan their own time the main advantage of distance learning. $51 \%$ of full time and $48 \%$ of part time students agreed with this conclusion. $53 \%$ of full time and $56 \%$ of part time note the increase of self-study skills. $34 \%$ full time respondents and $49 \%$ part time respondents consider that transport savings is the main advantage of distance learning. There was a place for notes in a free form in the survey, where most of the students pointed the increasing of an academic setting on their self-study. The students have had more homework in online format: «The teachers give us more homework than earlier, because they think if we are on distance learning, we have more free time. When all of them do it, we do not have time at all»- told us the full time education student. However, there are many new online opportunities for better learning. Most of the students pointed that they have an opportunity to chat with their teacher $(92 \%$ of full time students and $96 \%$ of part time students). $52 \%$ of full time students and $72 \%$ of part time students did the interactive tasks on the university's digital educational platform Moodle (tests, surveys etc.).

The data about the visual content is a bit different: $79 \%$ surveyed of full time students and $69 \%$ of part time students attended online lections and workshops. However, more than two thirds of respondents tried to perform with presentations on the online sessions at least once. Finally, «an individual work with teachers online in video chat». More than a half, 56\% of full time students and $64 \%$ of part time students used this tool. Meanwhile, only one third of students can control their academic record in their personal account, regardless of the education form.

The respondents call the lack of communication as a main disadvantage of distance learning: $79 \%$ of full-time students said that they do not have enough communication with fellow students and teachers.

Table 1. Forms of education that students use in the transition to a distance-learning format.

\begin{tabular}{|l|c|c|}
\hline \multirow{2}{*}{$\begin{array}{c}\text { Forms of education used in the transition to a distance } \\
\text { learning format }\end{array}$} & \multicolumn{2}{|c|}{$\begin{array}{c}\text { Responses of students (\% of the } \\
\text { number of respondents) }\end{array}$} \\
\cline { 2 - 3 } & $\begin{array}{c}\text { Full-time } \\
\text { students }\end{array}$ & $\begin{array}{c}\text { Part-time } \\
\text { students }\end{array}$ \\
\hline $\begin{array}{l}\text { Watching live lectures in online format (with the ability to } \\
\text { ask questions), online workshops (group classes) }\end{array}$ & 62 & 79 \\
\hline $\begin{array}{l}\text { Preforming at online workshops (group classes) with a } \\
\text { presentation on a given topic }\end{array}$ & 76 & 78 \\
\hline Performing interactive tasks in Moodle (tests, surveys, etc.). & 72,3 & 72,3 \\
\hline Chatting with teachers, exchange of documents & 92 & \\
\hline Controlling the academic record in a personal account & 34 & 26 \\
\hline An individual work with teacher, using a video chat & 56 & 64 \\
\hline
\end{tabular}


The nature of students' notes lets us to make a conclusion that most of them engaged in the distance learning, developed in new online learning formats, but they regarded it as a forced temporary measure not as an alternative of traditional education.

The self-assessment of professional competences, conducted in the study, shows that the students are very critical to their professional skills, which they got due to distance learning regardless of the form of education (Table 2).

Table 2. Indicators of self-assessment of students ' professional competencies.

\begin{tabular}{|c|c|c|c|c|c|}
\hline \multirow{2}{*}{$\begin{array}{c}\text { Form of } \\
\text { education }\end{array}$} & Indicator & \begin{tabular}{c} 
Competention \\
\cline { 3 - 6 } \\
Ability to \\
communicate
\end{tabular} & $\begin{array}{c}\text { Ability } \\
\text { to } \\
\text { work } \\
\text { in team }\end{array}$ & $\begin{array}{c}\text { Ability to } \\
\text { self- } \\
\text { organizatio } \\
\text { n and self- } \\
\text { education }\end{array}$ & $\begin{array}{c}\text { Ability to solve the standard } \\
\text { tasks in professional activity } \\
\text { on the basis of information } \\
\text { and bibliographic culture } \\
\text { with the use of information } \\
\text { and communication } \\
\text { technologies }\end{array}$ \\
\hline Full-time & $\begin{array}{c}\text { Median } \\
\text { ful-time }\end{array}$ & 4 & 3 & 4 & 4 \\
\hline Part-time & Median & 3 & 3 & 3 & 4 \\
\hline & part-time & & & & \\
\hline
\end{tabular}

The correlation analysis the statistically significant connections between indicators: selfassessment self-organization, self-education, and assessment of distance learning quality (table 3). It is statistically reliable that, if students highly evaluate the quality of distance education, its forms and the overall organization of the online learning process, their assessment of the ability to self-organize and self-educate is also high. The higher is the assessment of distance learning, the more the self-assessment to ability to self-organization, self- learning and self-development.

Table 3. Indicators of the connection of self-assessment of the ability to self-organization and selfeducation and the assessment of distance learning quality.

\begin{tabular}{|c|c|c|c|}
\hline Testee & Indicators & $\begin{array}{l}\text { Self-assessment of the } \\
\text { ability to self-organization } \\
\text { and self-education }\end{array}$ & $\begin{array}{l}\text { Assessment of } \\
\text { distance learning } \\
\text { quality }\end{array}$ \\
\hline Full-time education & Median full-time & 4 & 9 \\
\hline Part-time education & Median part-time & 3 & 8 \\
\hline Full-time education & Average Full-time & 4,45 & 9,04 \\
\hline Full-time education & Average Part-time & 3,25 & 6,91 \\
\hline Part-time education & Standart deviation full-time & 0,51 & 0,86 \\
\hline Part-time education & Standart deviation part-time & 0,67 & 2,40 \\
\hline Full-time Part-time education & Correlation coefficient & 0,744 & 0,744 \\
\hline
\end{tabular}




\section{Discussion}

The previous studies confirm the fact: self-development is a conscious process, which a person does without any external influence, using only his own internal resources for the increasing, his potential abilities.

In conditions of distance learning, the self-development is a process of harmonization of the future professional's needs and opportunities, pointed at optimal self-realization in the future profession. The self- education is an integral component of self-development, which is the main way of learning in distance education. That is why the connection between selfdevelopment and distance learning is quite close. The distance learning has a positive potential for developing the students' self- organization and self-development. The developing of self-organization's skills is the basis of online learning. It is important to introduce into distance education. Such tools that contribute to the professional selfdevelopment of specialists, and are based on the inclusion of the main mechanisms of selforganization and self-education of the individual.

We focused on the intellectual type of self-development, connected with more rational using of distance learning tools and aimed at achieving high results at psychological pedagogical activity.

The using of distance learning educational technologies, which focused on selfdevelopment of the future psychological and pedagogical specialists, should include not only transferring professional knowledge, but the developing of technical skills of work with information, processing and interpretation of empirical data, conducting monitoring studies, and experience in planning activities using online resources. As a result, it becomes possible to achieve a sufficient quality of specialist training for the implementation of professional tasks in the context of digital education. We are talking about a professional who is able to choose sources of information analyze and synthesize knowledge; aimed at improving the existing experience and striving for professional mastery.

The practical importance of the study is in the assessment of importance of distance learning for professional self-development of future specialists. The results of the study let us to argue the necessity of returning to the traditional forms of professional learning using the effectiveness of the new level online technologies.

\section{Conclusions}

The view of distance learning as an open system and a promising field of application of information technologies is increasingly strengthened at the present stage of social development.

The use of distance and online technologies positively affects the degree of perception of information by the future specialist, developing the functions necessary for planning and designing activities in the process of professional training. The distance format of communication with teacher changes the role models of professional training participants. It positions the student as a coordinator of knowledges, but the teacher is an interpreter of these knowledges.

We found that the students-participants of the study highlight the next advantages of the online learning:

-opportunity to get an education regardless of geolocation;

-opportunity to get a better education because of the new online technologies;

-opportunity to learn best practices through distance learning;

-opportunity to learn information and communication technologies, " gadgets»;

-high learning speed;

-display of self-organization and independence; 
Our study showed that the personal offline contact is necessary for future specialists not only for better learning, but also as a main motivator.

The lack of personal connection between a teacher and a student, the lack of live contact and emotional exchange decrease the understanding of material and weakens the interest in the study.

The technical difficulties is important disadvantage of online learning.

However, online learning opens the different opportunities for future specialists and they can get a range of professional skills that are mostly useful in his field of activity. This way of learning forms the self-organization's skills. It increases an intellectual level and lets the student to get the profession regardless of geolocation and the existing skills.

\section{References}

1. M.S. Biryukova, Technology of self-development of social teachers in the system of continuing professional education, Bulletin of the Kostroma State University. Series: Pedagogy. psychology. sociokinetics 23 (1), 115-117 (2017)

2. S.P. Grushevskij, O.V. Ivanova, The main directions of professional and personal selfdevelopment of future teachers at the university, Polythematic network electronic scientific journal of the Kuban State Agrarian University 131, 1015-1024 (2017) DOI: 10.21515/1990-4665-131-083

3. N.I. Sergeeva, Professional and personal self-development as a goal of professional growth of a teacher, Modern problems of science and education 2-1, 499 (2015)

4. Yu.V. Sharonin, Professional self-development of a teacher, Academia. Pedagogical Journal of the Moscow Region 1 (11), 20-22 (2017)

5. E.Yu. Azbukina, L.V. Voloshina, Spiritual values and personal potential of pedagogy, Bulletin of TSPU 4 (132), 38-41 (2013)

6. V.M. Miniyarov, A.E. Esterle, Factors of professional self-development of a teacherpsychologist in the course of professional activity, Bulletin of the Peoples ' Friendship University of Russia.- Series: Psychology and Pedagogy 1, 14, 26-37 (2017) DOI:10.22363/2313-1683-2017-14-1-26-37

7. D. Makovec, The teacher's role and professional development, International Journal of Cognitive Research in Science, Engineering and Education 6, 2 (2018) DOI:10.5937/ijcrsee1802033M

8. I. Noben, J.F. Deinum, W.H.A. Hofman, How is a professional development programme related to the development of university teachers' self-efficacy beliefs and teaching conceptions, Studies in Educational Evaluation 68, 1, 00966 (2021) DOI: https://doi.org/10.1016/j.stueduc.2020.100966

9. B.S. Haug, S.M. Mork, Acknowledging teachers' individual starting conditions and zones of development in the course of professional development, Teaching and Teacher Education 86, 102929 (2019) DOI: https://doi.org/10.1016/j.tate.2019.102929

10. S. Prestridge, Categorising teachers' use of social media for their professional learning: A self-generating professional learning paradigm, Computers \& Education 129, 143 158 (2019) https://doi.org/10.1016/j.compedu.2018.11.003

11. A. Suchodoletz, F.M. Jamil, A.A. Ross, A. Larsen, B.K. Hamre, Personal and contextual factors associated with growth in preschool teachers' self-efficacy beliefs during a longitudinal professional development study, Teaching and Teacher Education 75, 278289 (2018) DOI: https://doi.org/10.1016/j.tate.2018.07.009 
12. D.J. Osman, J.R. Warner, Measuring teacher motivation: The missing link between professional development and practice, Teaching and Teacher Education 92, 103064 (2020) DOI: https://doi.org/10.1016/j.tate.2020.103064

13. J.C. Rubin, Third spaces and tensions: Teacher experiences in an international professional development program, Teaching and Teacher Education 95, 103141 (2020) DOI: https://doi.org/10.1016/j.tate.2020.103141

14. D. Richter, M. Kleinknecht, A. Gröschner, What motivates teachers to participate in professional development? An empirical investigation of motivational orientations and the uptake of formal learning opportunities, Teaching and Teacher Education 86, 102929 (2019) DOI: https://doi.org/10.1016/j.tate.2019.102929

15. L. Rutten, Toward a theory of action for practitioner inquiry as professional development in preserviceteacher education, Teaching and Teacher Education 97, 103194 (2021) DOI: https://doi.org/10.1016/j.tate.2020.103194

16. G. Chen, A visual learning analytics (VLA) approach to video-based teacher professional development: Impact on teachers' beliefs, self-efficacy, and classroom talk practice, Computers \& Education 144, $103670 \quad$ (2020) DOI: https://doi.org/10.1016/j.compedu.2019.103670

17. S. Choi, X. Mao, Teacher autonomy for improving teacher self-efficacy in multicultural classrooms: A cross-national study of professional development in multicultural education, International Journal of Educational Research 105, 101711 (2021) DOI: https://doi.org/10.1016/j.ijer.2020.101711

18. T. Rutherford, J. Long, G. Farkas, Teacher value for professional development, selfefficacy, and student outcomes within a digital mathematics intervention, Contemporary Educational Psychology 51, 22-36 DOI:https://doi.org/10.1016/j.cedpsych.2017.05.005

19. A-K. Schindler, T. Seidel, A. Gröschner, Acknowledging teachers' individual starting conditions and zones of development in the course of professional development, Teaching and Teacher Education 100, $103281 \quad$ (2021) https://doi.org/10.1016/j.tate.2021.103281

20. M.B Aksu., Ç. Apaydın, G. Kasalak, Novice teacher self-efficacy belief: a study of scale development, International Online Journal of Education and Teaching 1(4), 262-276 (2014) http://iojet.org/index.php/IOJET/article/view/58/80

21. S. Prestridge, Categorising teachers' use of social media for their professional learning: A self-generating professional learning paradigm, Computers \& Education 129, 143158 (2019) https://doi.org/10.1016/j.compedu.2018.11.003 